\title{
ASUPAN ZAT BESI, ASAM FOLAT, DAN SENG TERHADAP KADAR HEMOGLOBIN PADA IBU HAMIL DI PUSKESMAS PACCERAKKANG KECAMATAN BIRINGAKANAYA KOTA
}

\author{
Abdullah Tamrin ${ }^{1}$, Aisya Hendrik ${ }^{2}$, Retno Sri Lestari ${ }^{1}$ \\ ${ }^{1}$ Jurusan Gizi, Politeknik Kesehatan Kemenkes, Makassar \\ ${ }^{2}$ Alumni Jurusan Gizi, Politeknik Kesehatan Kemenkes, Makassar \\ *) E-mail aisyahendrik@poltekkes-mks.ac.id/085299876621
}

\begin{abstract}
Anemia is a health problem that is often found in developing countries including indonesia. Iron deficiency anemia often occurs in pregnant women. Other micronutrient deficiencies such as folic and zinc and copper also play a role in the occurrence of anemia in pregnancy. The purpose of the study was to determine the relationship of iron determine the relationship of iron, folid acid, and zinc intake to hemoglobin levels in pregnant women in Paccerakkang health center Biringkanaya district Makassar city. This type of research was observational with a cross sectional stud design. The sample in this study were pregnant women who had normal hemoglobin levels of 15 people and abnormal hemoglobin levels of 17 people who examined at Paccerakkang health center Biringkanaya district, Makassar city. Iron intake, folid acid and zinc were obtained by using the 24 hour recall method and the respondents identity data was obtained from direct interviews using a questionnaire while the hemoglobin data was obtained through hemoglobin examination at Paccerakkang health center Biringkanaya district, Makassar city. The results of the analysis between the relationship between iron intake and hemoglobin levels with $p$ value $=0,010$ which means there is a relationship between iron and hemoglobin level. The results of the analysis between the relationship of folic acid intake with hemoglobin levels with $p$ value $=0,020$ which means there is a relationship between folid acid intake and hemoglobin level. The results of the analysis between the relationship between zinc intake and hemoglobin level were $p=0,015$ which means that there is a relationship between zinc intake and hemoglobin level
\end{abstract}

Keywords : iron intake of zinc, folic acid and hemoglobin levels

\section{PENDAHULUAN}

Anemia merupakan salah satu faktor penyebab tidak langsung kematian ibu hamil. Angka kematian ibu (AKI) di Indonesia adalah tertinggi bila dibandingkan dengan negara ASEAN lainya. Perempuan yang meninggal karena komplikasi selama kehamilan dan persalinan mengalami penurunan pada tahun 2013 sebesar 289.00 orang. Target penurunan angka kematian ibu sebesar $75 \%$ antara tahun 1990 dan 2015 (WHO, 2015). Jika perempuan mengalami anemia akan sangat berbahaya pada waktu hamil dan melahirkan. Perempuan yang menderita anemia akan berpotensi melahirkan bayi dengan berat badan lahir rendah (BBLR) (kurang dari 2,5 kg). Selain itu, anemia 
dapat mengakibatkan kematian baik pada ibu maupun bayi pada waktu proses persalinan (Rajab, 2009).

Menurut Riset Kesehatan Dasar (Riskesdas) tahun 2007 mendapatkan pravelensi anemia pada ibu hamil sebesar 24,5\%. Pada Riskesdas tahun 2010 pravelensi anemia pada ibu hamil bertahan pada angka 24,5\%. Pada Riskesdas tahun 2013 pravelensi anemia pada ibu hamil 37,1 $\%$. Dan pada Riskesdas tahun 2018, terjadi peningkatan ibu hamil anemia di Indonesia yaitu $48,9 \%$. Dengan proporsi anemia ibu hamil menurut umur $15-24$ tahun $(84,6 \%)$, umur 25-34 tahun (33,7\%), umur 35-44 tahun $(33,6 \%)$, dan umur 45-54 tahun (24\%). Jadi anemia yang terjadi di Indonesia tiap tahunya meningkat. Jika anemia tiap tahunya meningkatkan akan menyebabkan resiko kematin ibu 3,7 kali lebih tinggi jika dibandingkan dengan ibu yang tidak anemia (Riskesdas, 2018).

Penyebab utama anemia gizi adalah karena konsumsi zat besi yang tidak cukup, konsumsi zat besi yang rendah dan pola makan yang sebagian besar terdiri dari nasi dan menu yang kurang beranekaragam. Konsumsi zat besi dari makanan tersebut sering lebih rendah dari dua pertiga kecukupan konsumsi zat besi yang dianjurkan dan susunan menu makanan yang dikonsumsi tergolong pada tipe makanan yang rendah absorbsi zat besinya (Moehji, 2008). Seng merupakan zat gizi mikro yang mempengaruhi metabolisme besi. Seng dapat berinteraksi dengan besi secara langsung maupun tidak langsung. Peranan seng dan sintesis sebagai protein termasuk protein pengangkut besi yaitu transferin merupakan interaksi tidak langsung. Peranan seng seng yang bekerja hampir pada semua metabolisme tubuh, dalam pembentukan sel darah merah dengan membantu enzim karbonik anhidrase esensial untuk menjaga keseimbangan asam basa. Selain itu, seng membantu enzim karbonik anhidrase merangsang produksi HCL. Lambung yang mampu meningkatkan kadar hemoglobin (Widhyari, 2012).

Selain itu, asam folat berfungsi sebagai pembentukan sel darah merah dan penting dalam tumbuh kembang janin yang normal. Defiseinsi asam folat dapat menyebabkan anemia megalobkastic macrocytic (Ariani, 2017). Asam folat untuk mencukupi kebutuhan nya bisa dilakukan dengan mengosumsi sumber makanan seperti sayuran hijau, buah bewarna gelap dan gandum. Dan seng paling banyak adalah sumber protein hewani, terutama daging, hati, kerang, dan telur (Ariani, 2017).

Dari uraian tersebut kami akan melakukan penelitian tentang pengaruh tingkat asupan zat besi, asam folat, dan seng terhadap kadar hemoglobin pada ibu hamil di Puskesmas Paccerakkang Kecamatan Biringkanaya Kota Makassar.

\section{METODE}

\section{Desain, Tempat dan Waktu}

Jenis penelitian yang digunakan dalam penelitian ini adalah observasional dengan rancangan cross sectional study, yaitu suatu rancangan untuk melakukan analisis data yang sifatnya telah terjadi atau sedang berlangsung dalam populasi penelitian, dengan modal analisis secara deskriptif yang dapat memberikan gambaran serta dapat pula menentukan kita ke arah suatu hipotesis hubungan sebab akibat atau faktor penyebab yang dapat dianalisi melalui pengamatan lanjutan. Penelitian dilakukan di Puskesmas Paccerkkang Kecamatan Biringkanaya Kota Makassar, waktu penelitian dilaksanakan pada bulan mei dan juni 2019.

Populasi, Sampel dan Cara Pengambilan Sampel

Sampel pada penelitian ini sebanyak 32 orang ibu hamil. Sampel dalam penelitian ini adalah Ibu hamil yang usia kehamilanya Trimester I, II, dan III. Ibu hamil yang memiliki kadar hemoglobin yang rendah sebanyak 17 orang dan ibu hamil yang memiliki kadar hemoglobin 
normal sebanyak 15 orang, yang memeriksakan kehamilanya dan bersedia menjadi sampel pada tanggal 05 mei sampai 08 mei 2019. Pengambilan sampel dilakukan secara Purposive Sampling yaitu ibu hamil di Puskesmas Paccerakkang.

\section{Jenis dan Cara Pengumpulan Data}

Cara pengumpulan data dilakukan dengan mengumpulkan data primer dan data sekunder. Data primer Data primer diperoleh melalui wawancara langsung dengan menggunakan kuesioner meliputi identitas responden, riwayat kehamilan, dan asupan zat besi, asam folat, dan seng yang di perolah dengan menggunakan metode recall 24 jam selama 2 hari. Sedangkan data hemoglobin diperoleh dari ruang laboratorium kemudian di catat di buku pemeriksaan hemoglobin ibu hamil yang datang memeriksa kehamilan. Data sekunder meliputi profil Puskemas Paccerakkang.

\section{Pengolahan dan Analisis Data}

Pengolahan data dapat diperoleh dengan melalui wawancara secara langsung untuk mengetahui identitas responden, dan riwayat kehamilan. Serta data hemoglobin yang diperoleh dari buku pemeriksaan hemoglobin. Kemudian data diolah dengan menggunakan program Stastic Program For Sosial (SPSS). Data asupan gizi ibu hamil yaitu asupan zat besi, asam folat, dan

\section{HASIL}

Tabel 1

Hubungan Asupan Zat Besi Dengan Kadar Hemoglobin Pada Ibu Hamil di Puskesmas Paccerakkang Kecamatan Biringkanaya Kota Makassar

\begin{tabular}{lccccccc}
\hline \multirow{2}{*}{$\begin{array}{c}\text { Asupan Zat } \\
\text { Besi }\end{array}$} & \multicolumn{3}{c}{ Kategori Hemoglobin } & \multicolumn{3}{c}{ Total } & \multirow{2}{*}{$\mathrm{p}$} \\
\cline { 2 - 7 } & Normal & $\%$ & Anemia & $\%$ & $\mathrm{n}$ & $\%$ & \\
\hline Baik & 8 & 25 & 0 & 0 & 8 & 25 & 0,010 \\
Kurang & 7 & 21,8 & 17 & 53,1 & 24 & 75 & \\
\hline Total & 15 & 46,8 & 17 & 53,1 & 32 & 100 & \\
\hline
\end{tabular}

Dari data tabel diatas terdapat asupan zat besi dengan kategori baik terdapat 8 orang $(25 \%)$ memiliki seng di peroleh melalui recall 24 jam yang dilakukan sebanyak 2 kali. Hasilnya dianalisis ke dalam bentuk zat gizi dengan menggunakan Nutrisurvey Program. Dan kemudian dianalisi menggunakan Stastic Program For Sosial (SPSS). Analisis data dilakukan dengan menguji hipotesisi nol $\left(\mathrm{H}_{0}\right)$ dengan menggunakan rumus chi square $\left(\mathrm{X}^{2}\right)$ untuk mengetahui ada tidaknya hubungan variabel dependen dengan variabel independen analisis data meliputi :

a. Analisis Univariat (Analisis Deskriptif), bertujuan untuk menjelaskan atau medeskripsikan karateristik setiap variabel penelitian. Hasil dari analisis ini menghasilkan distribusi frekuensi dan presentase dari tiap variabel.

b. Analisis Bivariat, dilakukan terhadap dua variabel yang diduga berhubungan atau mempunyai korelasi. Hubungan antara variabel akan dianalisis menggunakan uji beda t-test (independent sample test). Analisis dengan metode ini bertujuan untuk membandingkan dua rata-rata kelompok yang tidak berhubungan. Data yang diolah dan dianalisis selanjutnya disajikan dalam bentuk tabel/grafik yang disertai dengan penjelasan dalam bentuk narasi. 
yang memiliki hemoglobin kurang atau anemia sebanyak 17 orang $(53,1 \%)$.Hasil analisis menunjukan bahwa ada hubungan asupan zat besi dengan kadar hemoglobin pada ibu hamil $(\mathrm{p}=0,010)$

Tabel 2

Hubungan Asupan Asam Folat Dengan Kadar Hemoglobin Pada Ibu Hamil di Puskesmas Paccerakkang Kecamatan Biringkanaya Kota Makassar

\begin{tabular}{cccccccc}
\hline Asupan Asam & \multicolumn{3}{c}{ Kategori Hemoglobin } & \multicolumn{3}{c}{ Total } & $\mathrm{p}$ \\
Folat & Normal & $\%$ & Anemia & $\%$ & $\mathrm{n}$ & $\%$ & \\
\hline Baik & 7 & 21,8 & 0 & 0 & 7 & 21,8 & 0,020 \\
Kurang & 8 & 25 & 17 & 53,1 & 25 & 78,1 & \\
\hline Total & 15 & 46,8 & 17 & 53,1 & 32 & 100 & \\
\hline
\end{tabular}

Dari data tabel diatas terdapat 7 orang $(21,8 \%)$ asupan asam folat kategori kurang memiliki kadar hemoglobin sebanyak 15 orang $(46,8 \%)$. Sedangkan asupan asam folat kurang terdapat 8 orang $(25 \%)$ asupan asam folat kurang memiliki kadar hemoglobin rendah atau anemia sebanyak 17 orang $(53,1 \%)$. Hasil analisis menunjukan bahwa ada hubungan asupan asam folat dengan kadar hemoglobin pada ibu hamil $(\mathrm{p}=0,020)$

Tabel 3

Hubungan Asupan Seng Dengan Kadar Hemoglobin Pada Ibu Hamil di Puskesmas Paccerakkang Kecamatan Biringkanaya Kota Makassar

\begin{tabular}{cccccccc}
\hline \multirow{2}{*}{ Asupan Seng } & \multicolumn{3}{c}{ Kadar Hemoglobin } & \multicolumn{3}{c}{ Total } & \multirow{2}{*}{ p } \\
& Normal & $\%$ & Anemia & $\%$ & $\mathrm{n}$ & $\%$ & \\
\hline Baik & 5 & 15,6 & 0 & 0 & 5 & 15,6 & 0,015 \\
Kurang & 10 & 31,2 & 17 & 53,1 & 27 & 84,3 & \\
\hline Total & 15 & 46,8 & 17 & 53,1 & 32 & 100 & \\
\hline
\end{tabular}

Dari data diatas terdapat 5 orang $(15,6 \%)$ yang memiliki asupan seng kurang dan memiliki kadar hemoglobin normal sebanyak 15 orang $(46,8 \%)$, sedangkan asupan seng terdapat 10 orang $(31,2 \%)$ yang memiliki asupan seng kurang dan memiliki kadar hemoglobin kurang atau anemia sebanyak 17 orang $(53,1 \%)$. Hasil analisis menunjukan bahwa ada hubungan asupan asam folat dengan kadar hemoglobin pada ibu hamil $(\mathrm{p}=0,015)$

Hasil analisis uji Chi Square diketahui bahwa ada hubungan asupan zat besi, asam folat dan seng terhadap kadar hemoglobin ibu hamil.

\section{PEMBAHASAN}

Ibu hamil pada masa kehamilan keperluan akan zat-zat makanan bertambah dan terjadi pula perubahan-perubahan dalam darah dan sumsum tulang. Jumlah darah akan bertambahn banyak selama kehamilan, yang lazim disebut hiderimia atau hypervolemia. Akan tetapi bertambahnya sel-sel darah kurang bila dibandingkan dengan bertambahnya plasma 
sehingga terjadi pengenceran darah (Evariny, 2010).

Zat besi adalah suatu komponen dari berbagai enzim yang mempengaruhi seluruh reaksi kimia yang penting dalam tubuh. Zat besi juga merupakan komponen dari hemoglobin yang memungkinkan sel darah merah membawa oksigen dari mengantarkanya ke jaringan tubuh. Makanan mengandung 2 jenis zat besi yaitu : Zat besi hem, yang terutama ditemukan dalam makanan produk hewani. Zat besi non hem, yang merupakan lebih dari $85 \%$ zat besi dalam makanan sehari-hari.

Hem diserap lebih baik dari pada non hem. Tetapi penyerapan zat besi non hem akan meningkat jika dikonsumsi bersamaan dengan protein hewani dan vitamin $\mathrm{C}$. sebelum diserap di dalam lambung zat besi disebabkan dari ikatan organik seperti protein. Sebagian besar zat besi dalam bentuk ferri direduksi menjadi bentuk fero. Hal ini terjadi dalam suasana asam di dalam lambung dengan adanya HCL dan vitamin $\mathrm{C}$ yang terdapat dalam makanan (Nadimin, 2004). Hasil penelitian menunjukan bahwa asupan zat besi $(\mathrm{Fe})$ dengan kategori baik 8 orang $(25 \%)$ memiliki hemoglobin normal sebanyak 15 orang $(46,8 \%)$. Hal ini disebabkan sebagian besar telah memenuhi 80\% standar kebutuhan AKG (Angka Kecukupan Giz). Sedangkan terdapat 24 orang $(75 \%)$ dengan kategori asupan kurang memiliki hemoglobin kurang/anemia sebanyak 17 orang $(53,1 \%)$. Hasil analisis menunjukan bahwa ada hubungan asupan zat besi dengan hemoglobin pada ibu hamil $(\mathrm{p}=0,010)$.

Folat terdapat luas didalam bahan makanan terutama dalam bentuk poliglutamat. Folat terutama terdapat dalam sayuran hijau (istilah folat berasal dari bahasa latin, folium yang berarti daun hijau) hati, daging tanpa lemak, serealia utuh, bijibijian, kacang-kacangan. Vitamin $\mathrm{C}$ yang ada dalam jeruk menghambat kerusakan folat. Bahan makanan yang tidak banyak mengandung folat adalah susu, telur, umbi- umbian dan buah, kecuali jeruk (Almatsier, 2008). Hasil penelitian menunjukan bahwa asupan asam folat dengan kategori baik 7 orang $(21,8 \%)$ memiliki hemoglobin normal sebanyak 15 orang $(46,8 \%)$ Hal ini disebabkan sebagian besar telah memenuhi 80\% standar kebutuhan AKG (Angka Kecukupan Giz). Sedangkan terdapat 25 orang $(78,1 \%)$ dengan kategori asupan kurang memiliki hemoglobin kurang/anemia sebanyak 17 orang $(53,1 \%)$. Hasil analisis menunjukan bahwa ada hubungan asupan asam folat dengan hemoglobin pada ibu hamil ( $p=0,020)$.

Status seng ibu hamil penting karena berkaiatan dengan kekurangan kehamilan, namun demikian mekanisme hubungan tersebut belum dapat dijelaskan. Dari penelitian yang pernah dilakukan menunjukan status seng ibu hamil yang rendah berdampak pada peningkatan kejadian absorpsi dan risiko bayi berat badan lahir rendah (BBLR) (Khasanah, 2003).Hasil penelitian menunjukan bahwa asupan seng dengan kategori baik 5 orang $(15,6 \%)$ memiliki hemoglobin normal sebanyak 15 orang $(46,8 \%)$. Hal ini disebabkan sebagian besar telah memenuhi 80\% standar kebutuhan AKG (Angka Kecukupan Giz). Sedangkan terdapat 27 orang $(84,3 \%)$ dengan kategori asupan kurang memiliki hemoglobin kurang/anemia sebanyak 17 orang $(53,1 \%)$. Hasil analisis menunjukan bahwa ada hubungan asupan seng dengan hemoglobin pada ibu hamil $(\mathrm{p}=0,015)$.

\section{KESIMPULAN}

1. Hasil analisis menunjukan bahwa ada hubungan antara asupan zat besi dengan hemoglobin $(\mathrm{p}=0,010)$

2. Hasil analisis menunjukan bahwa ada hubungan antara asupan asam folat dengan hemoglobin $(\mathrm{p}=0,020)$

3. Hasil analisis menunjukan bahwa ada hubungan antara asupan seng dengan hemoglobin $(\mathrm{p}=0,015)$ 


\section{SARAN}

1. Salah satu cara untuk meningkatkan hemoglobin saat hamil, dengan mencukupi asupan zat besi baik secara alami dari makanan sehair-hari, serta konsumsi suplemen. Selain itu, konsumsi sayuran berdaun hijau, buahbuah segar dan suplemen asam folat dengan vitamin B kompleks dapat meningkatkan kadar hemoglobin.

2. Perlunya meningkatkan asupan kurang pada ibu hamil dapat dilakukan dengan memberikan KIE (Komunikasi, Informasi, Edukasi) tentang makanan yang baik kepada ibu hamil agar ibu hamil memiliki bekal pengetahuan gizi yang baik sehingga terhindar dari kekurangan gizi terutama KEK (Kekurangan Energi Kronis).

3. Kejadian anemia pada ibu hamil dapat berdampak pada kehamilan. Ibu hamil hendaknya memperhatikan pola konsumsi gizi, pola istirahat, dan faktorfaktor yang mampu menurunkan resiko anemia ketika hamil. karena kejadian anemia pada ibu hamil sangat beresiko terjadi kematian dalam masa kehamilan.

\section{DAFTAR PUSTAKA}

Ariani, Ayu P. (2017). Ilmu Gizi. Yogyakarta : Nuha Medika

Almatsier S . (2008) Prinsip Dasar Ilmu Gizi. Gramedia Pustaka Utama. Jakarta

Evariny A (2010). Masalah Umum Kehamilan. http://wwwhypnobirthing.web.id (diakses 10 juni 2019)

Khasanah Nur, (2003) Hubungan Status Protein, Besi, Seng, Vitamin A, Folat dan Antropometri ibu hamil trimester II dengan bayi BBLR. Tesis program Pascasarjana Universitas Diponegoro Semarang

Kementrian Kesehatan Republik Indonesia. (2018). Laporan Hasil Riset Kesehatan Dasar (Riskesdas). Jakarta : Kementrian Kesehatan RI. https://www.depkes.go.id (diakses 20 januari 2019).

Moehji.S.(2012). Ilmu Gizi .Jakarta: Bratara Karya Sastra.

Rajab, Wahyudin.(2009). Buku Ajar Epidemiologi untuk Mahasiswa Kebidanan. Jakarta : EGC

Widhyari SD, (2012). Peran dan Dampak Defisiensi Zinc terhadap sistem tanggap kebal. Wartazoa vol.22 no. 3 